\title{
Pengembangan Sistem Informasi Monitoring Kehadiran Dosen Secara Realtime Berbasis Web
}

\section{Gede Aditra Pradnyana ${ }^{1 *}$, A.A. Gede Raka Wahyu Brahma²}

1Jurusan Pendidikan Teknik Informatika/FTK, Universitas Pendidikan Ganesha

2 Program Studi Teknik Informatika, STMIK STIKOM

\section{A R T I C L E I N F O \\ Article history: \\ Received 19 January 2020 \\ Received in revised form \\ 10 February 2020 \\ Accepted 12 March 2020 \\ Available online 25 April \\ 2020 \\ Kata Kunci: \\ Dosen, informasi, kehadiran, sistem}

Keywords:

lecturers, information,

attendance, systems

\begin{abstract}
A B S T R A K
Dalam kegiatan proses perkuliahan di institusi pendidikan tidak akan terlepas dari interaksi antara dosen dan mahasiswa. Dalam berinteraksi, informasi kehadiran dosen di kampus saat ini sangat diperlukan. Selain bermanfaat bagi mahasiswa, informasi kehadiran dosen juga sangat diperlukan dalam evaluasi kinerja dosen oleh bagian akademik atau bagian yang terkait lainnya. Saat ini proses absensi dosen yang baru diterapkan di STMIK STIKOM Indonesia dilakukan dengan menggunakan mesin absensi sidik jari yang terdapat di masingmasing ruang dosen. Laporan kehadiran dosen yang dihasilkan oleh mesin selanjutnya di rekapitulasi oleh pihak akademik untuk dijadikan bahan evaluasi dosen. Permasalahan yang terjadi adalah kerap mahasiswa sulit memperoleh informasi kehadiran dosen di kampus. Mahasiswa yang ingin bertemu dengan seorang dosen kerap harus ke kampus dengan percuma karena dosen yang dicari tidak ada di tempat. Dari sisi dosen, sering terjadi masalah dimana dosen lupa apakah dirinya sudah melakukan absensi pada mesin sidik jari atau belum. Dosen juga kerap mengalami kesusahan dalam memberikan informasi jika terlambat karena suatu kendala ataupun tidak dapat hadir di kampus. Pada penelitian ini dibangun sebuah sistem informasi kehadiran dosen di STMIK STIKOM Indonesia. Sistem informasi kehadiran dosen merupakan sistem yang mampu memberikan informasi yang cepat dan tepat mengenai kehadiran seorang dosen di kampus. Dari hasil pengujian diperoleh kesimpulan bahwa sistem informasi kehadiran dosen yang dibangun telah mampu berjalan sesuai dengan rancangan dan yang diharapkan.
\end{abstract}

A B S T R A C T

In the teaching and learning process in educational institutions can not be separated from the interaction between lecturer and students. In that interaction, information regarding the attendance of lectux rers on campus today is very necessary. Besides beneficial for students, lecturer presence information can also be used in the evaluation of the performance of a lecturer by the academic or other related parts. This time the attendance presence of a lecturer who applied in STMIK STIKOM Indonesia done using fingerprint attendance machine located at each faculty room. The presence reports generated by fingerprint machine then calculated by the academic authorities to be a lecturer evaluation report.. Problems often occur is difficult to obtain information about the student's presence on campus lecturer. Students who wish to meet with a teacher often had to go to the campus with useless because the lecturer is sought not in place. In terms of faculty, there are problems where the lecturer could not remember if she had done on the machine fingerprint attendance or not. Lecturers also often experience difficulties in providing the information if he is late or can not be present on campus. In this study developed a presence information systems lecturer in STMIK STIKOM

\footnotetext{
Corresponding author.

E-mail addresses: gede.aditra@undiksha.ac.id (Gede Aditra Pradnyana)
} 
Indonesia. Presence information systems lecturer is a system that can provide quick and precise information about the presence of a professor on campus. From the testing that has been done, it can be concluded that the information system that has been built capable of running as designed and expected.

Copyright (C) Universitas Pendidikan Ganesha. All rights reserved.

\section{Pendahuluan}

Saat ini teknologi memegang andil yang cukup besar didalam kehidupan manusia, hampir di setiap waktu dan tempat masyarakat tergantung pada teknologi. Apalagi saat ini teknologi banyak mengalami kemajuan dalam segala segi, sehingga semakin memudahkan masyarakat untuk menggunakannya. Adapun dampak dari kemajuan teknologi itu sendiri salah satunya adalah mempermudah penggunanya mendapatkan dan mengolah informasi. Cara ini sangat efisien bagi penggunanya, karena dengan waktu yang cepat pengguna dapat memperoleh dan mengolah data maupun informasi yang akurat kapanpun dan dimanapun mereka berada. Oleh karena itu, saat ini banyak instansi ataupun perusahaan menuangkan segala informasi didalamnya melalui sistem, hal ini tentu membutuhkan sumber daya manusia sebagai penyedianya. Dan oleh karena itu, maka kita harus memiliki kemampuan untuk dalam menghadapi kemajuan teknologi ini. Suatu sistem itu sendiri menurut Jogiyanto (2005:34) adalah suatu jaringan kerja dari prosedurprosedur yang saling berhubungan, berkumpul bersama-sama untuk melakukan suatu kegiatan atau menyelesaikan suatu sasaran yang tertentu.

Dan informasi menurut Hanif (2007:9) ialah data yang telah diolah menjadi bentuk yang berarti bagi penerimanya dan bermanfaat dalam pengambilan keputusan saat ini atau mendatang. Dengan demikian sistem informasi merupakan kesatuan yang terdiri dari interaksi beberapa jaringan kerja yang berusaha mencapai tujuan yang sama (Faizal, 2017).

Perkembangan ilmu pengetahuan dan teknologi yang sangat pesat saat ini menjadikan teknologi informasi sesuatu hal yang penting dalam kehidupan sehari-hari. Teknologi Informasi membantu pekerjaan dengan menyediakan informasi dan melakukan berbagai tugas yang berhubungan dengan pengolahan informasi. Pemanfaatan teknologi informasi telah mencakup berbagai bidang, mulai dari bidang ekonomi, bisnis sampai pendidikan. Bidang pendidikan tidak akan jauh dari pendidikan formal yaitu sekolah. Pemanfaatan teknologi informasi membantu sekolah dalam mengelola data yang ada, dimana data tersebut digunakan untuk mendukung pengambilan keputusan sekolah terhadap permasalahan yang sedang dihadapi. Sistem pengolahan dan manejemen informasi yang baik, akan sangat berpengaruh dalam peningkatkan kinerja yang efektif dan efisien (Ermatita, 2016).

Perkembangan ilmu pengetahuan di segala bidang dalam era globalisasi saat ini begitu pesat. Terutama dalam bidang teknologi informasi yang semakin maju seiring dengan kebutuhan pemakai (user) untuk memperoleh suatu karya atau inovasi maksimal serta memperoleh kemudahan dalam segala aktivitas untuk mencapai suatu tujuan. Salah satu tujuan yang ingin dicapai adalah tersedianya informasi yang akurat, cepat, dan tepat dalam mengatasi suatu permasalahan. Berbagai jenis perangkat lunak (software) telah diciptakan guna mengatasi permasalahan informasi, termasuk informasi kehadiran dosen pada suatu perguruan tinggi. Dalam kegiatan proses perkuliahan di institusi pendidikan tidak akan terlepas dari interaksi antara dosen dan mahasiswa. Dalam berinteraksi, informasi kehadiran dosen di kampus saat ini sangat diperlukan. Selain bermanfaat bagi mahasiswa, informasi kehadiran dosen juga sangat diperlukan dalam evaluasi kinerja seorang dosen oleh bagian akademik atau bagian yang terkait lainnya.

STMIK STIKOM Indonesia merupakan salah satu perguruan tingi swasta di Provinsi Bali yang menyelenggaran pendidikan dalam bidang teknologi dan informasi. Saat ini proses absensi dosen yang baru diterapkan di STMIK STIKOM Indonesia dilakukan dengan menggunakan mesin absensi sidik jari yang terdapat di masing-masing ruang dosen. Laporan kehadiran dosen yang dihasilkan oleh mesin selanjutnya di rekapitulasi oleh pihak, untuk dijadikan bahan evaluasi dosen. Permasalahan yang terjadi adalah kerap mahasiswa sulit memperoleh informasi kehadiran dosen di kampus. Sistem absensi yang ada belum bisa memberikan informasi kehadiran dosen kepada mahasiswa tersebut. Disamping itu, kegiatan dosen yang tidak hanya di kampus kerap memberikan hambatan tersendiri bagi mahasiswa untuk mengetahui akan ada atau tidaknya seorang dosen di kampus. Mahasiswa yang ingin bertemu dengan seorang dosen kerap harus kekampus dengan percuma karena dosen yang dicari tidak ada di tempat. Dari sisi dosen, sering terjadi masalah dimana dosen lupa apakah dirinya sudah melakukan absensi pada mesin 
sidik jari atau belum. Dosen juga kerap mengalami kesusahan dalam memberikan informasi jika terlambat karena suatu kendala ataupun tidak dapat hadir di kampus. Selain absensi kehadiran dosen di kampus, STMIK STIKOM Indonesia juga menerapkan absensi dosen mengajar. Sistem absensi ini akan mencatat waktu seorang dosen memulai dan meangkhiri proses perkuliahan di suatu kelas. Keadaan yang ada saat ini, sistem absensi kehadiran dan absensi mengajar tidak saling terhubung dalam memberikan informasi kehadiran dosen di kampus. Mahasiswa yang ingin bertemu seorang dosen kerap harus menghubungi pihak akademik untuk mengetahui apakah dosen tersebut tidak ada diruangan karena sedang mengajar atau memang tidak hadir di kampus.

Berangkat dari gambaran permasalahan di atas, STMIK STIKOM Indonesia dirasa perlu untuk membangun sebuah sistem informasi kehadiran dosen. Sistem informasi kehadiran dosen merupakan sistem yang mampu memberikan informasi yang cepat dan tepat mengenai kehadiran seorang dosen di kampus. Sistem informasi ini merupakan sistem pelengkap dari sistem absensi yang sudah digunakan. Sistem informasi ini dibangun berbasis web agar informasi yang disediakan bisa diakses dimana saja dan kapan saja.

\section{Metode}

\section{A. Pengembangan Tahapan Penelitian}

Tahapan pertama pada penelitian ini adalah melakukan pendefinisian masalah yang ingin diselesaikan. Setelah mendefinisikan masalah yang ingin diselesaikan langkah selanjutnya adalah melakukan pengumpulan data untuk mendukung penyelesaian permasalahan yang dihadapi. Setelah data yang diperlukan terkumpul, data dianalisis sebagai dasar dalam pembuatan sistem. Dalam tahap ini juga didefinisikan kebutuhan-kebutuhan dalam pengembangan sistem. Perancangan dan pengembangan sistem dilakukan setelah kebutuhan-kebutuhan sistem dikumpulkan. Hasil penelitian ini diperoleh dari proses uji coba produk. Dengan mengacu pada aspek penilaian produk dan penerapannya di STMIK STIKOM Indonesia.

\section{B. Lokasi Penelitian}

Lokasi penelitian ini adalah di STMIK STIKOM Indonesia yang menyediakan objek penelitian berupa data dosen, jadwal shift dosen, dan jadwal mengajar dosen.

\section{Metode Pengumpulan Data}

Adapun teknik yang akan dipakai dalam pengumpulan data atau fakta adalah teknik kajian pustaka atau studi literatur. Tujuan dari teknik ini adalah untuk mendapatkan referensi sebagai pedoman untuk pembangunan sistem yang akan digunakan. Pengumpulan data dan informasi dilakukan dengan cara membaca berbagai buku, makalah dan bahan bacaan lain sebagaireferensi yang dapat dijadikan acuan dalam proses pembahasan masalah. Selain itu data dan informasi yang di butuhkan juga diperoleh dengan mengunjungi berbagai situs-situs terkait yang menyediakan berbagai informasi yang relevan dengan bahasan penelitian.

\section{Analisis Kebutuhan}

Analisis kebutuhan bertujuan untuk mendapatkan semua kebutuhan yang diperlukan dari sistem yang akan dibangun. Analisis kebutuhan dilakukan dengan mengidentifikasi semua kebutuhan sistem dan siapa saja yang terlibat di dalamnya. Analisis juga dilakukan untuk mengetahui kondisi lapangan yang ada sehingga dapat diketahui implementasi perangkat lunak yang akan digunakan.

\section{E. Hak Akses Pengguna dalam Sistem}

Pada Sistem Informasi Kehadiran Dosen ini terdapat tiga hak akses, yaitu Adminstrator, Operator, dan Dosen. Dosen hanya dapat melakukan proses absen saat hadir serta saat pulang dan melakukan proses pengubahan keterangan kehadiran sesuai dengan data dosen bersangkutan. Pengguna dengan hak akses operator dapat melakukan perubahan keterangan semua dosen yang terdaftar dan melihat laporan kehadiran seluruh dosen yang terdaftar. Hak akses adminstator adalah hak akses tertinggi yang mampu menggunakan seluruh fitur yang dimiliki sistem kecuali melakukan absensi dosen.

\section{F. Data Flow Diagram (DFD) Sistem Informasi Kehadiran Dosen}

Pada Gambar 1 berikut ini adalah gambar konteks diagram dari Sistem Informasi Kehadiran Dosen. Terdiri dari tiga external entity yaitu Adminstrator, Operator, Dosen dan satu proses. Konteks diagram ini merupakan gambaran umum dari sistem. Sistem ditunjukkan dengan satu lingkungan yang menggambarkan seluruh proses dalam sistem dan hubungannya dengan entitas (lingkungan luar sistem). 


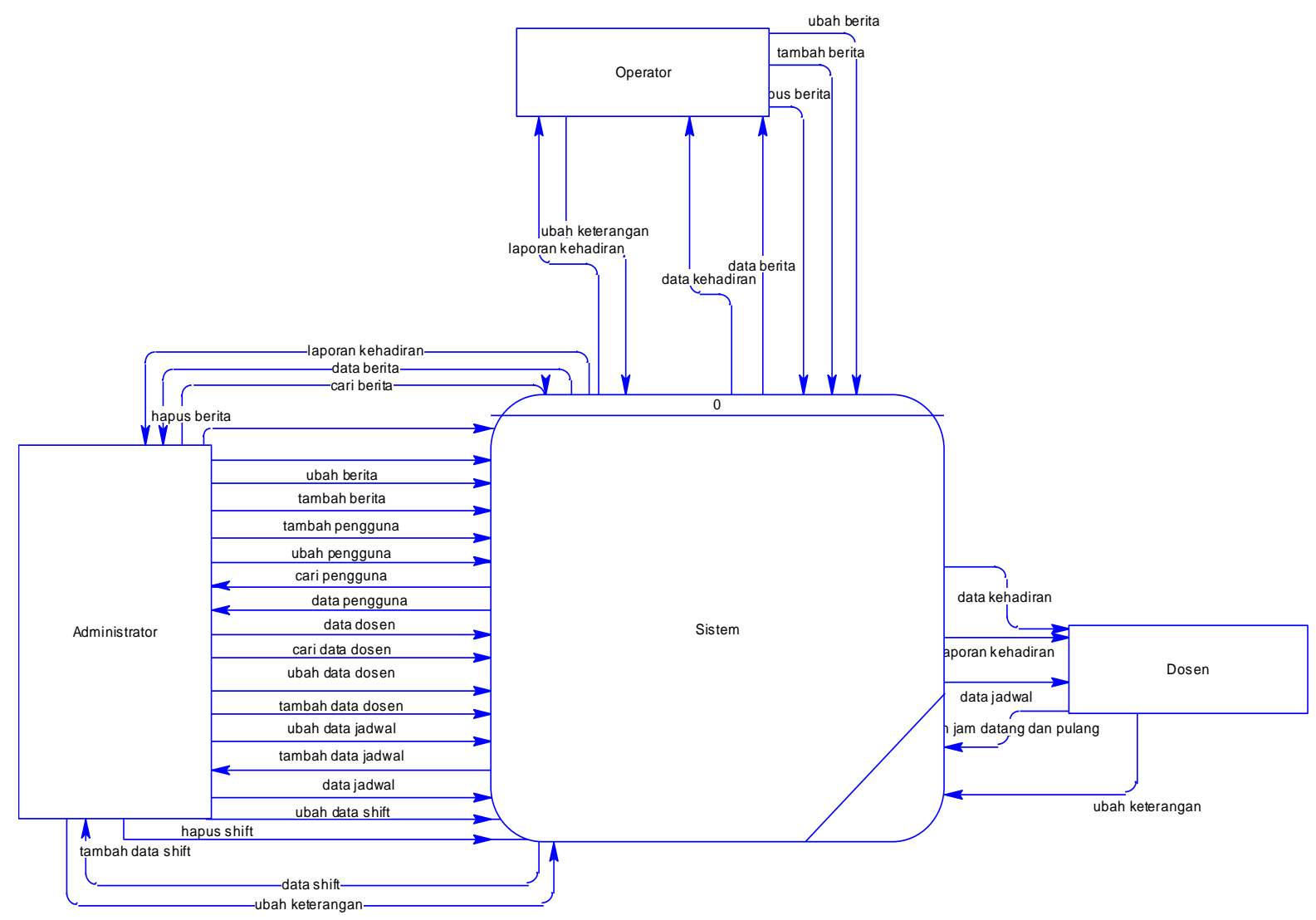

Gambar 1. Context Diagram Sistem Informasi Kehadiran Dosen

\section{G. Perancangan Basis Data}

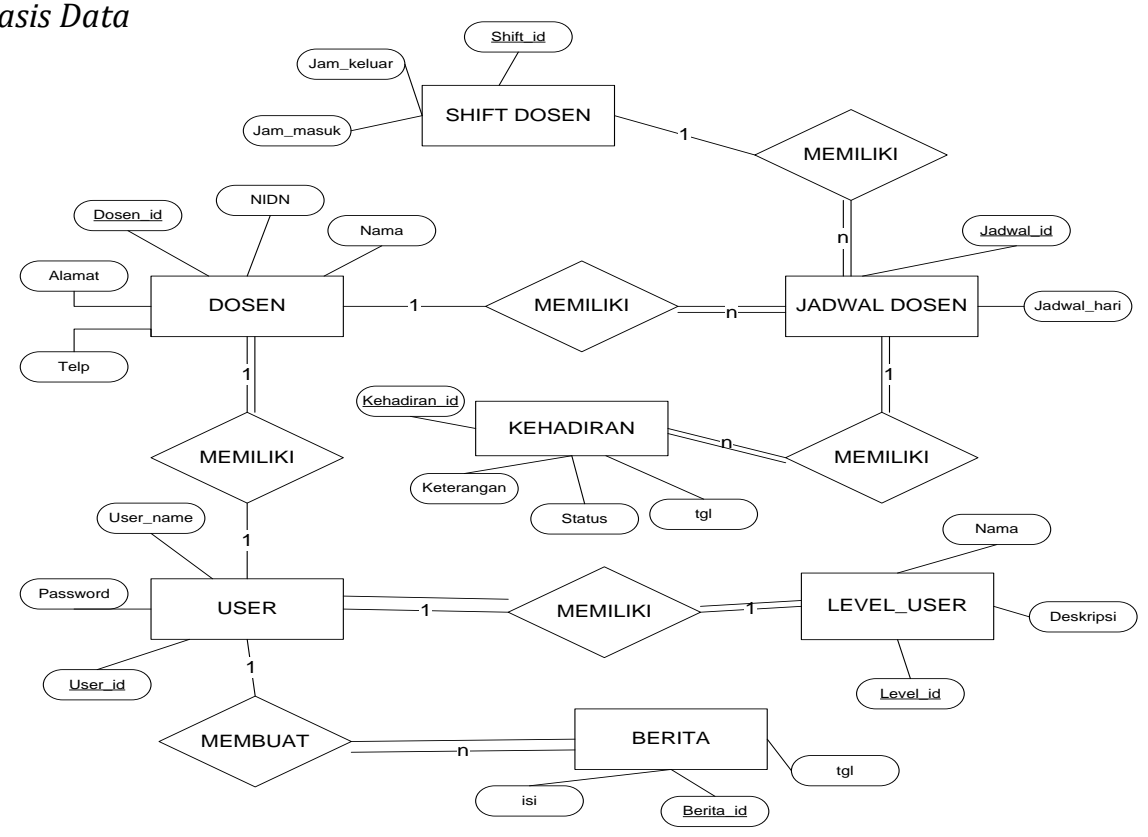

Gambar 2. ER-Diagram Sistem Informasi Kehadiran Dosen STMIK STIKOM Indonesia

Sistem informasi kehadiran dosen yang akan dibangun tentu saja menggunakan sistem database sebagai sistem penyimpanan datanya, maka dari itu perlu dilakukan perancangan desain database dengan membuat Entity Relationship Diagram (ERD) dari sistem. Pembuatan ERD sistem bertujuan untuk membuat rancangan awal database sebelum data akan disimpan dalam sistem database. Dalam 
perancangan ERD terdapat proses penentuan entitas-entitas yang terlibat, atribut yang dimiliki entitas tersebut, dan menentukan relasi antara entitas-entitas yang ada. ERD sistem informasi kehadiran dosen berbasis web dapat dilihat pada Gambar 2.. Setelah menggambarkan rancangan sistem database yang akan digunakan dalam bentuk ERD, rancangan yang ada dikembangkan kedalam model konseptual dan model fisik sesuai database management system (DBMS) yang akan digunakan. DBMS yang akan digunakan dalam pengembangan sistem viinformasi kehadiran dosen ini adalah MySQL 5.

\section{Hasil dan pembahasan}

\section{A. Kebutuhan Sistem}

Kebutuhan perangkat keras dan perangkat lunak minimal yang diperlukan dalam menjalankan sistem informasi kehadiran dosen ini antara lain :
a. Processor Intel Pentium IV atau lebih
b. $\quad$ Memory $500 \mathrm{Mb}$ atau lebih
c. $\quad$ Sistem operasi menggunakan Microsoft Windows 7 atau yang lebih tinggi
d. Web browser Mozilla Firefox atau Google ChromeSetelah melakukan perancangan, tahap selanjutnya adalah

B. Halaman Login
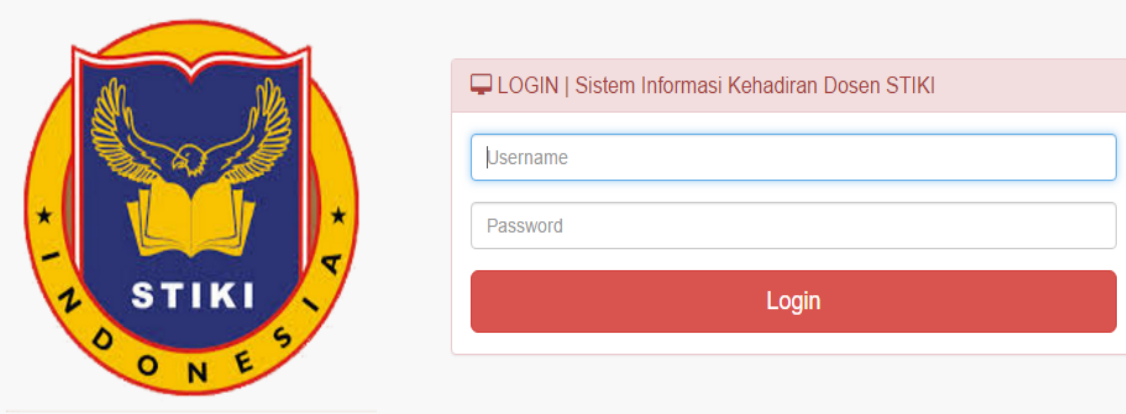

Gambar 3. Halaman Login Sistem Informasi Kehadiran

Gambar 3. merupakan halaman login sisten. Pada halaman login sistem, pengguna akan memasukkan username dan password kemudian memiih tombol login. Sistem akan otomatis membedakan hak akses pengguna berdasarkan username dan password. Hak akses atau level pengguna sistem dibedakan menjadi Administrator, Operator, dan Dosen.

\section{Halaman Utama}

Apabila proses login telah berhasil, sistem akan menampilkan halaman utama sesuai dengan hak akses pengguna. Halaman utama untuk pengguna level Administrator dapat dilihat pada Gambar 4. Halaman dibagi menjadi tiga bagian utama, yaitu bagian header, sidebar, dan bagian isi. Pada bagian header terdapat nama sistem dan nama pengguna yang sedang menggunakan sesuai akun. Bagian sidebar berisikan fitur-fitur yang terdapat pada sistem informasi kehadiran dosen ini. 


\section{Administrator Dashboard}
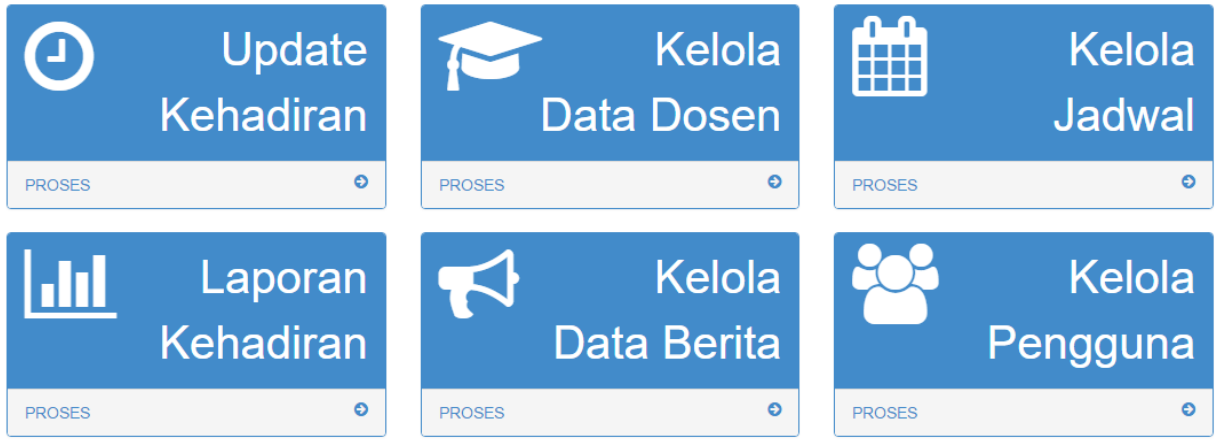

Gambar 4. Halaman Utama Administrator

D. Halaman Kelola Data Dosen

\begin{tabular}{|c|c|c|c|c|c|c|c|c|c|}
\hline (5.) SISTEM INFC & ADIRAN D & SEN STIKI & & & & & & \multicolumn{2}{|c|}{ 2 Gede Aditra Pradnyana } \\
\hline (-) Update Kehadiran & & & & & & & & & \\
\hline Kelola Data Dosen & \multicolumn{2}{|c|}{+ Buat Baru } & & & & & & & \\
\hline Kelola Jadwal & & & & & & & & & \\
\hline 三 Kelola Shift & \multicolumn{4}{|c|}{ Kelola Data Dosen } & & & & & \\
\hline W Laporan Kehadiran & \multirow{2}{*}{\multicolumn{2}{|c|}{ Menampilkan : $10 \vee$ data }} & & & & \multirow{2}{*}{\multicolumn{2}{|c|}{ Pencarian : }} & & \\
\hline Kelola Pengguna & & & $\hat{\nabla}$ & NIDN & $\hat{\nabla}$ & & & & $\hat{\nabla}$ \\
\hline \multirow[t]{6}{*}{ * Kelola Berita } & 1 & I Made Ardwi Pradnyana, S.T., M.T. & & 0818118602 & & EDetail & $\Delta$ Edit & in Hapus & \\
\hline & 2 & Brigida Arie Minartiningtyas, S.Kom., M.Kom. & & 08267687612 & & E Detail & Edit & 甶 Hapus & \\
\hline & 3 & I Nyoman Agus Suarya Putra, S.S.n., M.Sn & & 08876876 & & 婓Detail & Edit & mit Hapus & \\
\hline & 4 & Aniek Suryanti, S.Kom., M.Kom. & & 0826387632 & & EDetall & Edit & itit Hapus & \\
\hline & 5 & I Nyoman Anom Fajaraditya, S.Sn., M.Sn & & 086726836 & & EDetail & Edit & iti Hapus & \\
\hline & 6 & I Wayan Sudiarsa, S.T., M.Kom & & 082789278 & & E E Detail & Edit & Iin Hapus & \\
\hline
\end{tabular}

Gambar 5. Halaman Kelola Data Dosen

Proses kelola data dosen hanya dapat diakses oleh pengguna dengan level Adminstrator. Gambar 5 merupakan halaman kelola data dosen. Dosen-dosen yang tersimpan dalam sistem ditampilkan dalam bentul data grid. Proses yang dapat dilakukan adalah menambahkan data dosen baru, melihat detil data dosen, melakukan perubahan data dosen, dan hapus dosen. Pencarian data dosen dapat dilakukan dengan memasukkan kata kunci berupa nama dosen atau nomor induk dosen nasional (NIDN). Proses penambahan data dosen akan otomatis menambahkan dosen ke dalam pengguna sistem dengan level atau hak akses dosen.

\section{E. Halaman Kelola Shift}

Halaman kelola shift digunakan untuk menambahkan jenis shift yang akan digunakan pada jadwal kehadiran dosen. Halaman kelola shift dapat dilihat pada Gambar 6. Proses kelola shift hanya dapat diakses oleh pengguna dengan level Administrator. 


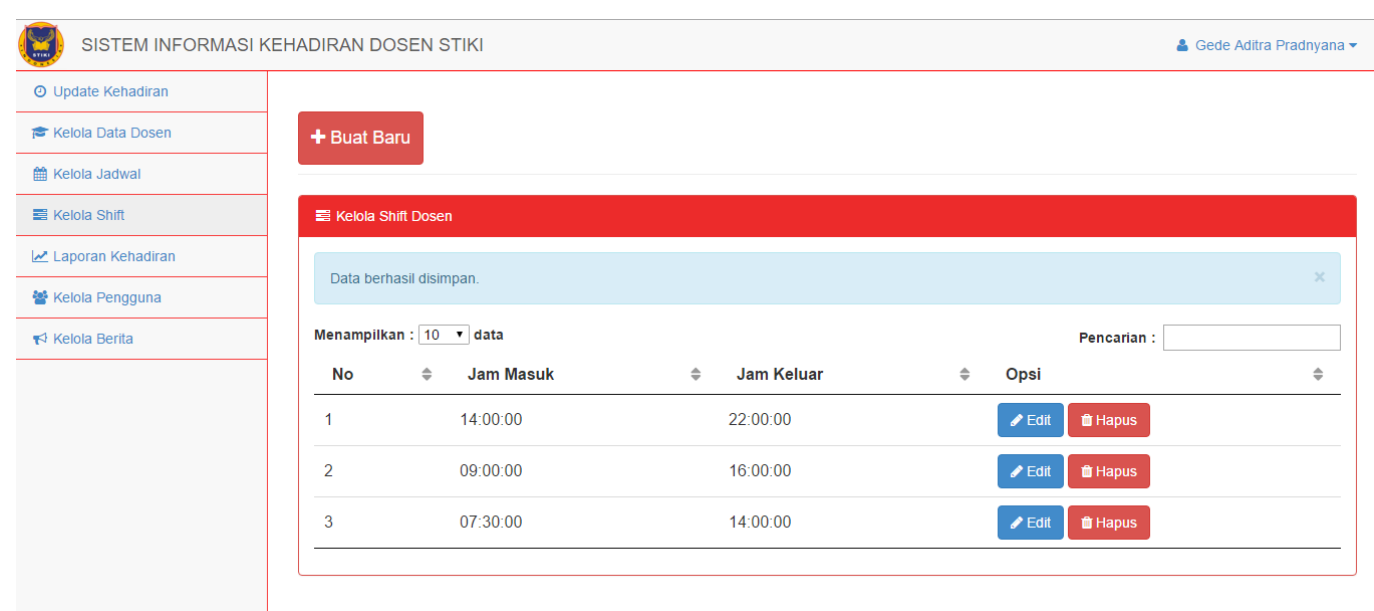

Gambar 6. Halaman Kelola Shift Dosen

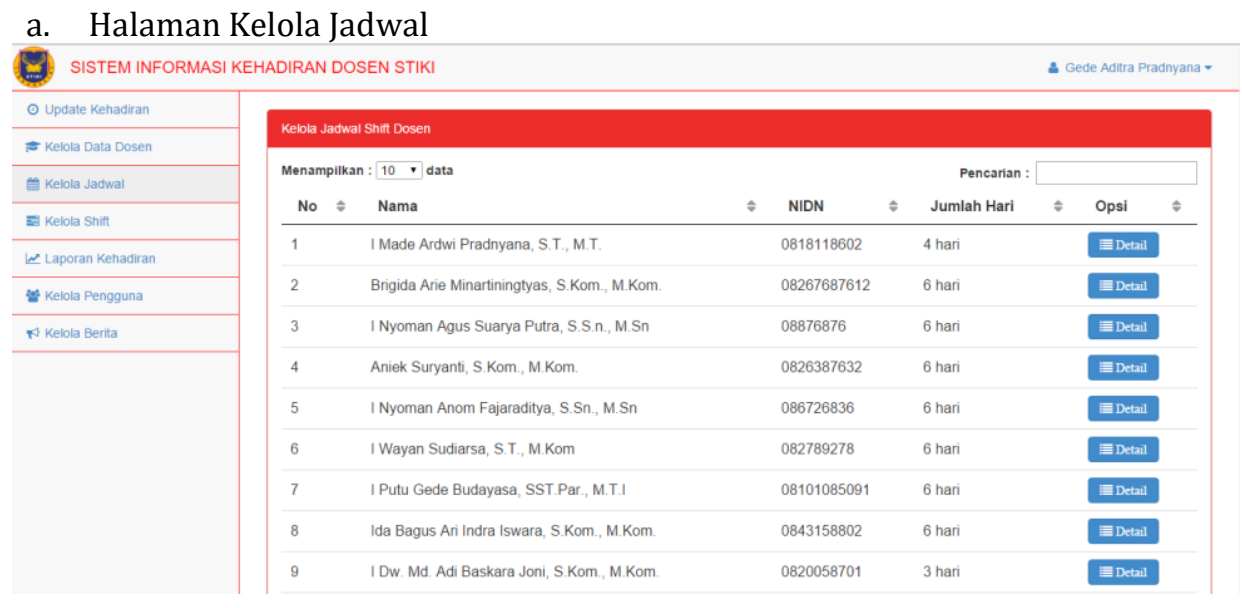

Gambar 7. Halaman Kelola Jadwal Dosen

Dosen-dosen yang telah terdaftar akan otomatis muncul di proses kelola jadwal. Data jadwal dosen ditampilkan dalam data grid. Kolom jumlah hari berisikan jumlah hari dengan shift yang telah ditentukan. Tampilan halaman kelola jadwal dapat dilihat pada Gambar 7. Untuk mengatur jadwal shift dosen sesuai hari yang dipilih dapat dilakukan dengan memilih tombol detail. Gambar 8 merupakan jadwal detil dari setiap dosen. Proses penambahan, pengubahan, dan penghapusan data jadwal hanya dapat dilakukan oleh pengguna dengan level Administrator, sedangkan pengguna dengan level Dosen hanya dapat melihat jadwal dosen seperti pada gambar 9.

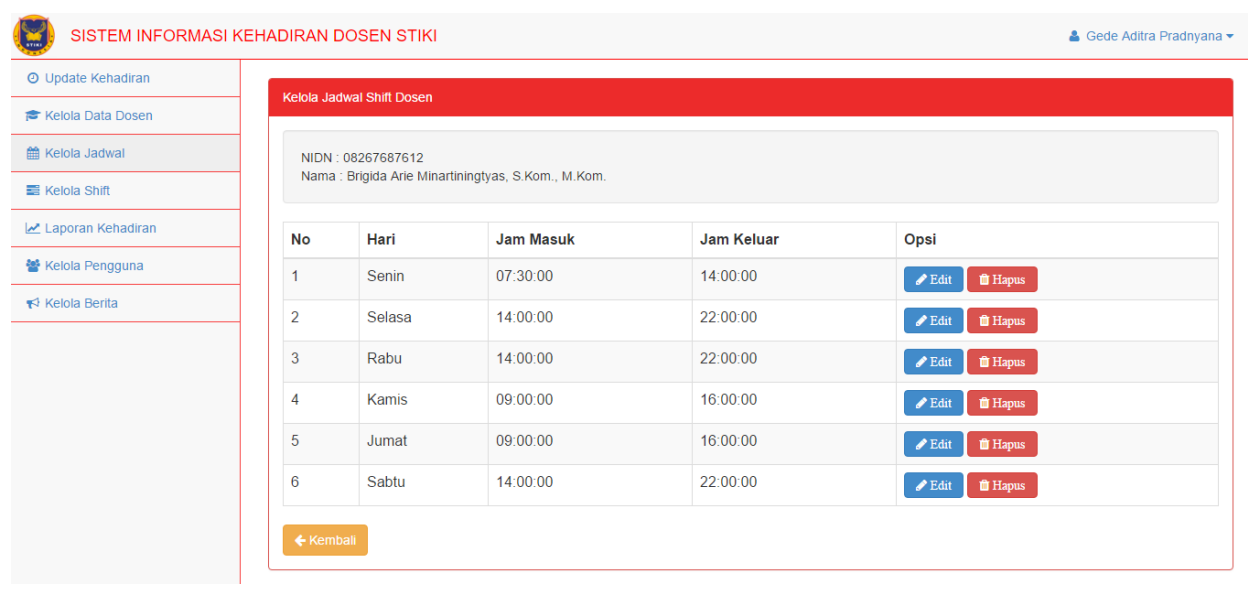

Gambar 8. Menambahkan Jadwal Dosen 


\begin{tabular}{|c|c|c|c|c|}
\hline \multicolumn{4}{|c|}{ (2.) SISTEM INFORMASI KEHADIRAN DOSEN STIKI } & \multirow[t]{2}{*}{ a Brigida Arie Minartiningtyas, S.Kom., M.Kom. - } \\
\hline Update Kehadiran & \multirow{2}{*}{\multicolumn{3}{|c|}{ 輩 Jadwal Dosen }} & \\
\hline E Jadwal Dosen & & & & \\
\hline \multirow[t]{8}{*}{ We- Laporan Kehadiran } & No & Hari & Shift & \\
\hline & 1 & Senin & $07: 30.00-14: 00.00$ & \\
\hline & 2 & Selasa & 14:00:00 - 22:00:00 & \\
\hline & 3 & Rabu & 14:00:00 - 22:00:00 & \\
\hline & 4 & Kamis & 09:00:00 - 16:00:00 & \\
\hline & 5 & Jumat & 09:00:00 - 16:00:00 & \\
\hline & 6 & Sabtu & $14: 00: 00-22: 00: 00$ & \\
\hline & & & & \\
\hline
\end{tabular}

\section{Gambar 9. Halaman Lihat Jadwal di Menu Dosen}

\section{F. Halaman Informasi Kehadiran Dosen}

Gambar 10 merupakan halaman informasi kehadiran dosen yang ditampilkan pada halaman depan web. Untuk melihat informasi ini pengguna tidak perlu melakukan login ke dalam sistem. Informasi ini akan akan diperbaharui secara otomatis dalam 5 menit. Informasi ini juga dapat diakses langsung oleh mahasiswa dengan mengetikkan alamat (url) web sistem informasi kehadiran dosen. Informasi yang ditampilkan antara lain : informasi jadwal shift dosen di hari tersebut, status dosen, keterangan dosen, dan pengumuman. Status dari seorang dosen adalah tidak hadir, hadir, dan sudah pulang.

\begin{tabular}{|c|c|c|c|}
\hline \multirow{2}{*}{$\begin{array}{l}\text { IMAGE } \\
\text { NOT } \\
\text { FOUNO }\end{array}$} & Brigida Arie Minartiningtyas, S.Kom., M.Kom. & \multirow[t]{2}{*}{ * SUDAH PULANG } & \multirow[t]{2}{*}{-} \\
\hline & ( $14: 00-22: 00$ & & \\
\hline \multirow{2}{*}{$\begin{array}{l}\text { IMAGE } \\
\text { NOT } \\
\text { FOUND }\end{array}$} & Gede Aditra Pradnyana, S.Kom., M.Kom. & x TIDAK HADIR & \multirow[t]{2}{*}{ Saya Telat 10 Menit } \\
\hline & (1) 14:00-22:00 & & \\
\hline \multirow{2}{*}{$\begin{array}{c}\text { IMAGE } \\
\text { NOT } \\
\text { FOUNO }\end{array}$} & Dwi Putra Githa, S.T., M.T. & $\checkmark$ HADIR & \multirow[t]{2}{*}{-} \\
\hline & (1) 09:00-16:00 & & \\
\hline \multirow{2}{*}{$\begin{array}{c}\text { IMAGE } \\
\text { MOOF } \\
\text { FOUNO }\end{array}$} & I Dw. Md. Adi Baskara Joni, S.Kom., M.Kom. & $\checkmark$ HADIR & \multirow[t]{2}{*}{ Sedang makan siang ya } \\
\hline & () Tidak Ada Jadwal & & \\
\hline \multirow{2}{*}{$\begin{array}{c}\text { MMGE } \\
\text { MOOF } \\
\text { FOUND }\end{array}$} & Ida Bagus Ari Indra Iswara, S.Kom., M.Kom. & × TIDAK HADIR & \multirow[t]{2}{*}{-} \\
\hline & (1) $14: 00-22: 00$ & & \\
\hline \multirow{2}{*}{$\begin{array}{l}\text { IMAGE } \\
\text { MOUT } \\
\text { FOUND }\end{array}$} & I Putu Gede Budayasa, SST.Par., M.T.I & x TIDAK HADIR & \multirow[t]{2}{*}{-} \\
\hline & () $14: 00-22: 00$ & & \\
\hline & 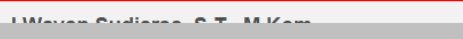 & 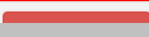 & \\
\hline
\end{tabular}

Gambar 10. Halaman Informasi Kehadiran Dosen

\section{G. Hasil Pengujian Sistem}

Setelah sistem diimplementasikan dengan baik, langkah selanjutnya adalah melakukan pengujian sistem. Pengujian sistem dilakukan dengan menggunakan metode black box testing. Metode black box testing digunakan untuk meyakinkan bahwa fitur-fitur atau fungsi-fungsi yang terdapat dalam sistem informasi yang dibangun sudah berjalan dengan baik. Pengujian dilakukan untuk meyakinkan kualitas dari sistem informasi kehadiran dosen yang telah dibangun. Adapun hasil dari pengujian sistem informasi kehadiran dosen dapat dilihat pada Tabel 1. 
Tabel 1. Hasil Pengujian Sistem

\begin{tabular}{cllll}
\hline No & \multicolumn{1}{c}{ Skenario Pengujian } & \multicolumn{1}{c}{ Hasil yang Diharapkan } & \multicolumn{2}{c}{ Hasil Sistem } \\
\hline 1. & $\begin{array}{l}\text { Memasukkan username } \\
\text { dan password yang benar }\end{array}$ & $\begin{array}{l}\text { Sistem menampilkan halaman utama } \\
\text { sistem }\end{array}$ & $\begin{array}{l}\text { Sesuai } \\
\text { diharapkan }\end{array}$ & yang \\
2. & $\begin{array}{l}\text { Memasukkan username } \\
\text { dan atau password yang }\end{array}$ & Sistem menampilkan pesan kesalahan & $\begin{array}{l}\text { Sesuai } \\
\text { diharapkan }\end{array}$ & yang \\
salah & $\begin{array}{l}\text { Memasukkan username } \\
\text { dan password kosong }\end{array}$ & Sistem menampilkan pesan kesalahan & $\begin{array}{l}\text { Sesuai } \\
\text { diharapkan }\end{array}$ & yang \\
& & &
\end{tabular}

4. Menambah data dosen dengan melengkapi semua isian pada form

5. Menambah data dosen dengan mengosongkan beberapa isian pada form

6. Mengubah sebuah data dosen

7. Mencari data dosen, dengan kata kunci yang terdapat pada data dosen yang ada.

8. Menambah data shift dosen dengan melengkapi semua isian pada form

9. Menambah data shift dosen dengan mengosongkan isian pada form

10. Menghapus salah satu data shift

11. Memilih detail jadwal dari seorang dosen

12. Mengatur shift seorang dosen dengan memilih shift yang ada.

13. Mengatur shift seorang dosen tanpa memilih shift yang ada.

14. Melakukan perubahan keterangan seorang dosen

15. Mencari data kehadiran dosen, dengan kata kunci yang terdapat pada data kehadiran dosen yang tersimpan.

16. Mencari data kehadiran dosen, dengan kata kunci yang tidak terdapat pada data kehadiran dosen yang tersimpan.
Memunculkan pesan bahwa data berhasil ditambahkan, kemudian menampilkan data terbaru Menampilkan pesan kesalahan, data tidak disimpan.

Memunculkan pesan bahwa data berhasil diubah, kemudian menampilkan data terbaru yang telah diubah

Menampilkan data yang dicari

Sesuai yang diharapkan

Sesuai yang diharapkan

Sesuai yang diharapkan

Memunculkan pesan bahwa data berhasil ditambahkan, kemudian menampilkan data terbaru

Menampilkan pesan kesalahan

Menampilkan konfirmasi data yang akan dihapus, kemudian menghapus data saat mendapat persetujuan.

Menampilkan detail dosen yang sesuai dengan yang dipilih

Menampilkan pesan data berhasil disimpan, dan menampilkan data shift terbaru serta tombol hapus dan ubah Menampilkan pesan kesalahan

Sesuai yang diharapkan

Menampilkan pesan bahwa data berhasil disimpan, menampilkan data keterangan dosen terbaru. Menampilkan data yang dicari

Sesuai yang diharapkan

Sesuai yang diharapkan

Sesuai yang diharapkan

Sesuai yang diharapkan

Sesuai yang diharapkan

Sesuai yang diharapkan

Sesuai yang diharapkan

Sesuai yang diharapkan

Menampilkan keterangan bahwa tidak ada data ditemukan
Sesuai yang diharapkan 


\section{Simpulan dan saran}

Berdasarkan hasil dan pembahasan yang dilakukan, adapun kesimpulan dari penelitian ini antara lain:

1. Penelitian ini dilakukan dengan beberapa tahapan yaitu pengumpulan data (primer dan sekunder), analisis kebutuhan sistem, perancangan sistem, pembangunan sistem, dan pengujian sistem.

2. Perancangan sistem secara umum terdiri dari dua tahapan utama, yaitu perancangan alur sistem dan perancangan basis data sistem. Perancangan alur sistem dilakukan dengan penggambaran dalam data flow diagram, dimulai dari context diagram sampai dengan data flow diagram level 1. Perancangan basis data sistem dilakukan dengan menggunakan entity relationship diagram serta penggambaran dalam phsyical data model serta conseptual data model.

3. Sistem kehadiran dosen berbasis web berhasil dibangun dengan menggunakan bahasa pemrograman PHP dan database MySQL. Adapun hak akses atau level pengguna dari sistem dibedakan menjadi tiga, yaitu level administrator, level operator, dan level dosen.

Proses pengujian sistem dilakukan dengan menggunakan metode black box testing. Dari hasil pengujian sistem informasi kehadiran dosen yang dibangun telah mampu berjalan sesuai dengan rancangan dan yang diharapkan.

\section{Daftar Rujukan}

Ermatita. 2016. Analisis Dan Perancangan Sistem Informasi Perpustakaan. Jurnal Sistem Informasi (JSI), VOL. 8, NO. 1, April 2016.

Faizal, Muhammad. 2017. Sistem Informasi Pengolahan Data Pegawai Berbasis Web (Studi Kasus Di Pt Perkebunan Nusantara Viii Tambaksari). Jurnal Teknologi Informasi dan Komunikasi STMIK Subang, Oktober 2017.

Hall, James, 2001. Sistem Informasi Akuntansi, Edisi Ketiga. Jakarta : Salemba Empat.

Hartono, Jogiyanto, 2005. Analisis \& Desain Sistem Informasi: pendekatan terstruktur teori dan praktik aplikasi bisnis. Yogyakarta : Penerbit Andi.

Jogiyanto, HM. 2005. Analisis dan Desain Sistem Informasi : pendekatan terstruktur teori dan praktik aplikasi bisnis. Yogyakarta : Penerbit Andi.

Laudon, Kenneth C. dan Loudon, Jane P, 2005. Sistem Informasi Manajemen, Mengelola Perusahaan Digital, Edisi 8. Yogyakarta : Penerbit Andi.

Limbong, Tonni. 2012. Perancangan Sistem Informasi Kehadiran Mengajar Dosen. Pelita Informatika Budi Darma, Vol 1.

Mulyasa, E., 2007. Kurikulum Berbasis Kompetensi. Bandung:Remaja Rodaskarya.

O’Brien, James A, 2005. Pengantar Sistem Informasi, Edisi Kedua Belas. Jakarta : Salemba Empat.

Simarmata, Janner. dan Paryudi, Iman. 2010. Basis Data. Yogyakarta : Penerbit Andi. 